\title{
From Homo-economicus to Homo-virtus: A System-Theoretic Model for Raising Moral Self-Awareness
}

\author{
Julian Friedland ${ }^{1} \cdot$ Benjamin M. Cole $^{2}$
}

Received: 9 June 2016/Accepted: 28 February 2017/Published online: 13 March 2017

(C) Springer Science+Business Media Dordrecht 2017

\begin{abstract}
There is growing concern that a global economic system fueled predominately by financial incentives may not maximize human flourishing and social welfare externalities. If so, this presents a challenge of how to get economic actors to adopt a more virtuous motivational mindset. Relying on historical, psychological, and philosophical research, we show how such a mindset can be instilled. First, we demonstrate that historically, financial self-interest has never in fact been the only guiding motive behind free markets, but that markets themselves are representations of our individual and collective moral identities. Building on this understanding, we review the research on how economic incentives crowd out virtueoriented concerns. We then introduce the concept of moral self-awareness (MSA), an evolving mindset informed by reflection on moral identity, namely what one's actions say about oneself given the impacts (positive or negative) on others or society that one's action may effect. MSA comprises three fundamental aspects of virtue-oriented reasoning: pride, shame, and guilt. Finally, we offer a fourstage model anchored in systems theory, yielding ever more refined motivating strategies for maximizing human flourishing and social welfare externalities.
\end{abstract}

Julian Friedland

friedlandj@gmail.com

Benjamin M. Cole

bmcole@fordham.edu

1 Department of Philosophy, University of Colorado Denver, Denver, CO, USA

2 Gabelli School of Business, Fordham University, New York, NY, USA
Keywords Capitalism $\cdot$ Economic incentives $\cdot$ Moral selfawareness - Moral motivation - Moral progress - Ethical decision making $\cdot$ Moral priding $\cdot$ Moral shaming $\cdot$ Positive externalities $\cdot$ Negative externalities

\section{Introduction}

Arguments in favor of a laissez-faire approach to the market rely on the premise that the actors involved in transactions are best able to make their own decisions without interference (Hayek 1945; Rothbard 2006). It is further argued that interference in the market creates unforeseen consequences, which drive up costs for transacting parties, creating inefficiencies in the allocation of resources. Government regulation, for example, is "the initiation of force against peaceful buyers and sellers [which] inevitably causes them to act against their best interests, or at least against what they believe to be their best interest" (Tannehill and Tannehill 2009, p. 19). Thus, if we hope to attain the highest levels of social welfare, we should get out of the way of the market and let the truly free market reign (Rothbard 2006).

Yet the outcomes that have resulted from the push globally to create freer markets and encourage capitalistic systems show mixed results (Chang 2008; Klein 2007) with some arguing that worsening inequality is an inevitable outcome of free market capitalism (Piketty 2014). While America's work ethic has remained strong (Na 2011), its pay ethic has shifted dramatically with the CEO-to-worker pay ratio ballooning $1000 \%$ since 1950 (Smith and Kuntz 2013). Since 2009, roughly 95\% of income gains have been appropriated by the top $1 \%$ of earners (Saez 2013), while others have suffered through financially painful and personally demoralizing long-term 
joblessness (Peck 2010). While the world has benefited from yield gains from seed technology innovation (Brookes and Barfoot 2009), we have lost roughly $90 \%$ of seed varieties (on average) of 63 different fruits and vegetables over the past century (Fowler and Mooney 1996, pp. 64-67). The western black rhinoceros is extinct, having been poached to death by those acting in their own selfinterest (Knight 2013).

Such realizations have generated calls for a utilitarian approach that seeks to maximize happiness for all stakeholders (Jones and Felps 2013), a new humanistic emphasis in management theory-one that looks beyond shareholder interests and toward society as a whole (Giacalone and Thompson 2006), creates shared value (Porter and Kramer 2006), considers the longer term (Barton 2011), employs less centralized governance models (Pirson and Turnbull 2011), or is guided by the intangible hand of an economy of esteem (Brennan and Pettit 2006). If we are to accept, along with these authors, that an economically self-interested view of corporate behavior (i.e., the shareholder maximization perspective) needs to be set aside and that more holistic views of corporate activity need to be embraced, the practical challenge is how to get managers, employees, shareholders, consumers, and other stakeholders to actually adopt such a holistic view when they have been immersed in an egoistic atmosphere so long at an institutional level via employment practices, advertising, public policy, education, and media. Surely, it will take more than benevolent CEOs or a restraining regulatory framework; often, it will take funding that will not necessarily be forthcoming without a broad-based motivational transformation across all stakeholders.

In this paper, we offer a therapeutic solution based on moral self-awareness-for ultimately, acting responsibly requires more than thinking in terms of financial (Friedman 1970) or reciprocal self-interest (Bosse et al. 2009). Otherwise, one runs the risk of rationalizing negative actions that are only problematic in the aggregate, such as Tragedy of the Commons scenarios (Diamond 2006; Hardin 1968). Reciprocally motivated thinking may well spur managers to increase worker pay, for example, to right perceived wrongs in the eyes of stakeholders who value just outcomes (Bosse et al. 2009), but it also may overlook other activities that undermine welfare indirectly or diffusively, or that cater to myopic, or misguided stakeholder demands. Our approach is to offer an alternative moral motivational construct better equipped to maximize social welfare and avoid dangerously unsustainable practices than strictly economic incentives. We advance a motivational paradigm built upon psychological and philosophical research, indicating that pride, shame, and guilt are strong moral motivators that can counteract the negative psychological effects of market capitalism by engaging moral progress. Finally, we connect our prescriptions to systems theory, describing what we see as the four stages toward moral self-awareness. We demonstrate how we can move from the basest level of receiving third-party feedback of the negative externalities we have wrought upon others to self-actualizing our values and, in the process, purposely creating positive externalities instead.

\section{The Moral Dimensions of Markets}

While the market is often characterized as a series of transactions between self-interested actors, organizational scholars over the past 30 years have demonstrated that those interactions are not devoid of reflection that we are not atomistic actors (Granovetter 1985; Lazerson 1995). Even when actors might be better off being calculatingly self-interested, they often are not (Baker 1984; Uzzi 1997). These insights have been vital in dispelling the myth of homo-economicus as the best approximation of the human actor in business settings. But what is often forgotten is that the very underpinnings of market transactions-specifically, (1) what can be owned and traded, (2) who can own and trade, and (3) the conditions under which trade may occur-already embody a moral assessment of who we are (Reich 2013), including the type of people we aspire to be. Indeed, the continuing moral progress of markets is realized by just such considerations.

\section{What Can Be Owned and Traded}

The first structural dimension of markets that is informed by our moral compass is what can be owned as property. It is simply unacceptable that anything can and should be allowed to become part of a transaction; our moral compass defines at any given moment in time what can be owned.

For centuries, humans were openly owned and traded as part of a global system of slavery (Wood 1997). And on strict utilitarian grounds, this would not necessarily be unjust if one could show that economic growth increased dramatically, thereby creating the greatest good for the greatest number. According to the 1790 Census, roughly $18 \%$ of the US population was slaves (University of Virginia 2004). These "other persons" were enumerated in the Constitution as equivalent of three-fifths of a person for the purposes of apportioning representation in Congress and were required to be returned to their owners "on Claim of the Party" should they escape their owners (US Constitution 1787). At the time, there was nothing more valuable than a woman of child-bearing age, who could be bred with male slaves of attractive attributes (e.g., strength and stamina) to produce other slaves (Koppelman 2010). This specification of what could be owned was enforced 
through constitutional reasoning, and through a terroristic police state that included slave militia, who used ruthlessness to keep the "property" from demanding "nonproperty" status (Bogus 1998).

Slave owners became brutally efficient at exploiting their property, appropriating an estimated $\$ 1$ trillion in unpaid labor through a highly efficient market (Swinton 1990). Many of the practices developed to extract the greatest value out of those assets-from production quotas to asset depreciation-are still used today in corporate America (Johnston 2013). Had efficiency, profits and economic importance been the sole arbiter of whether slave markets should continue, the moral progress that now makes us cringe at the idea of women being bred like cattle would never have been possible. That same position along the arc of moral progress also allows most of us to not cringe at the idea of cattle being bred and then slaughtered. Whereas we recognize the morally equivalent "human" nature of women of African descent and those of AngloSaxon descent, we still (broadly) do not recognize a morally equivalent "animal" nature of cows and humans (Steiner 2008). And while non-human animals still do not possess legal rights, moral philosophers throughout history have defended concern for all sentient beings (Bentham 1780; Singer 1981). This widening arc of moral consideration continues to generate new animal protection legislation (Wise 2000); a landmark ruling in the Oregon Supreme Court established that pets should not be considered mere property (State v. Newcomb, 2016).

As a society, we have struggled repeatedly to determine whether something can be owned and traded as property. Debates have arisen regarding payments to surrogate mothers (Spar 2006) and even the ability to patent living organisms and genetic sequences (SCOTUS 1980, 2013). So-called "dead peasant" policies allowed employers, who determine workload levels and workplace safety, to profit from the death of employees, often without their knowledge or permission (Sixel 2002). Sale of these policies (Martin 2003-2004) and their derivatives (Giacalone 2001), and the garnering of tax write-offs for them (Trinkaus and Giacalone 2002) beg the question: Who owns the right to profit from your death? When such policies were at their peak due to their tax benefits-with millions of policies sold-it was not you as an individual. In short, what can constitute property that can be owned or traded is a moral decision, and our moral progress demands we remember this.

\section{Who Can Own and Trade}

The second structural dimension of markets that is informed by our moral compass is who can own and trade. Children would benefit financially from trading labor for dollars, and thus, free market principles argue that children should be allowed to consummate the trade (Dessy and Pallage 2004). Those with a longer view of the child's life, however, might retort that options available to the child in the future-in terms of health, wealth generation, the search for potential mates, etc.- - would be enhanced if the child spent those same hours in school (Chang 2008). While wages from labor would certainly help a child in the short run, full-time education would help the child (and society) further in the long run. For this reason, many societies have deemed child labor abhorrent and illegal, though not all do so.

These restrictions did not just apply to labor, however. In the UK, from the early thirteenth century until the passage of the 1870 Married Women's Property Act, a woman "on marrying, relinquished her personal property - moveable property such as money, stocks, furniture, and livestock-to her husband's ownership; by law he was permitted to dispose of it at will at any time in the marriage and could even will it away at death" (Combs 2005, p. 1031). The 1870 Act gave married women rights over earnings in any occupation separate from her husband and secured them control over assets such as bank accounts and equity shares. A second Act was necessary in 1882 to give married women the right to all property that they owned or were entitled to receive at the time of marriage and after (Combs 2005, p. 1033). Similar acts were adopted in various states in the USA (Speth 1993). Belief that certain members of society cannot, or should not, own property or be able to trade in markets is a moral decision that reflects both who we are as a society and who we collectively aspire to be.

\section{The Conditions Under Which Trade May Occur}

The third structural dimension of markets that is informed by our moral compass is the conditions under which trade may occur. Free market proponents argue that the conditions of a sale are solely the concern of the transactors; if someone is wronged by the transaction, the victim can seek restitution. There are three problems with this argument: (1) what is enforceable through the court evolves, (2) information asymmetry between the buyer (who knows the true quality of the product or service being traded) and the seller (who does not) assures the latter will bear most of the risk, and (3) that not all dimensions of the transaction are priced into the particular trade (i.e., externalities exist). The third condition is particularly important for our model of moral self-awareness.

As an example of the first condition, when purchasing a home in 2003, one of the authors was surprised to discover "Modification of Building Restrictions" paperwork filed with the county register's office in 1940, which read: "No 
portion of said lots...shall be occupied by persons not of the Caucasian Race except as guests or servants domiciled with an owner or tenant." While such restrictions may have been defensible in a US court of law in 1940, the trade of property under such conditions has since been deemed unconstitutional in the years since. Thus, depending on what point in time one has found oneself, even consummated contracts may no longer be legally enforceable.

As an example of the second condition, for decades, buyers of health insurance in the US did not know the true nature of the policies they were purchasing. Insurance firms historically were allowed to accept monies from policy holders under the auspices that those monies were premiums for insurance payments that would cover expenses should the policy holder become sick, then "rescind" those policies if the policy holder ended up needing expenses covered. The modus operandi was to look for discrepancies between the patient's medical records and what was disclosed when the contract was signed. Failure to disclose common ailments such as acne was cause for policy termination (Girion 2009); naturally, no refund was given for any monies paid as premiums. One might ask why such determinations of missing medical information were not initiated at the start of the policy; it was not in the interest of insurers to do so. Insurer WellPoint, for example, "singled out women with breast cancer for aggressive investigation with the intent of cancelling their insurance" after accepting premium payments for years (Potter 2010, p. 74). Recognizing this hole in contract theory, which allowed the taking of monies under the auspices of insurance coverage that would never come, the US Congress acted to forbid rescissions for preexisting conditions through The Patient Protection and Affordable Care Act (Congress 2010).

Finally, as an example of the third condition, pollution is almost never fully priced into the transaction that yielded the externality. When a consumer buys electricity from a power producer, for example, in most nations, the price rarely includes the cost of the pollution streaming into rivers or blowing into the sky. And if there is regulation, firms generally are allowed to pollute up to a given level and usually avail themselves of the opportunity rather than work to reduce their pollution output to zero. The National Academy of the Sciences (2009) estimates that in 2005 alone, pollution from energy production and use created health and environmental damage totaling more than $\$ 120$ billion.

At the same time, positive externalities also may exist outside the market transaction. When an individual purchases a piece of software, the value derived from other users' ownership of the same software goes up. Individuals can more readily share files, comment on each other's work, and even collaborate on new projects as a result of these positive externalities. Firms also save billions of dollars a year not having to train employees how to "double click" on computer programs and type out email addresses (David 1985). Due to ubiquity of use of software, firms presume that any new employee will have certain skillsets, even if the employer never verifies those skillsets at the point of contracting. To do so would be incredibly costly to firms (Coase 1937); instead, firms (and society more broadly) rely on these positive externalities regularly.

As one can see, what can be owned and traded, who can engage in ownership and trade, and the conditions that we allow for trade all communicate something about what we value as a society. "The mere existence of a market may provide social information about the appropriateness of trading, rendering [the morally circumspect] more allowable" going forward (Falk and Szech 2013, p. 708). This is the key lesson inherent in these three moral dimensions of markets.

\section{Free Market's Crisis of Character}

It should be clear now that arguments to simply "get out of the way" of the market are untenable; the market is both infused with, and a vehicle of, our moral compass and thus constantly demands our interference in pursuit of the world that we desire to build and the people we desire to be. Building on this shared understanding of the moral underpinnings of markets, we now turn our attention to the moral failings of markets as observed today.

The economically self-interested rational actor model is a powerful, yet simple economic model of human behavior that assumes that individuals combine the goods and bads as they see them into a single expected utility function and act so as to maximize that function (Atiq 2014). Although economists recognize that behavior may be driven by higher motives including morality, beauty, loyalty, and truth, the use of this model has been pushed beyond traditional microeconomic activity to nearly every aspect of human behavior from marriage (Pollak 2000) to workplace discrimination (Arrow 1971).

At the heart of this model is the idea that by pursuing solely one's own self-interest, social welfare more broadly is also improved. This theorized relationship was perhaps most inspired by the following passage by Adam Smith:

It is not from the benevolence of the butcher, the brewer, or the baker that we expect our dinner, but from their regard to their own interest. We address ourselves, not to their humanity, but to their self-love. And never talk to them of our own necessities but of their advantages. Nobody but a beggar chooses to depend chiefly on the benevolence of his fellow citizens. (Smith 2008, I, II. 2). 
Any careful account of the Great Crash of 2008, however, will show that the public interest may not, in fact, be enhanced by economically self-interested actions. There is ample evidence that unqualified individuals took on loans that they could not afford (Conway 2008), that assets that only met AA default rate standards were systematically stamped with AAA ratings by rating agencies to pocket fees (Griffin and Tang 2011) and that finance executives knowingly duped investors (US SEC 2010). Estimates place total losses from the crash at $\$ 10.2$ trillion (BusinessWeek 2009). From April 2006 to May 2009, the S\&P/ Case-Shiller Home Price Composite-10 Index shows that housing prices dropped 33\%, which meant that even those who already owned their homes suffered tremendouslythe drop in housing prices prevented people who did not engage in wrongdoing from being able to sell their homes, for example, to take a job in other states. Clearly, such externalities are unacceptable, even though they came about with homeowners, rating agencies, and financial firms prioritizing their own self-interests.

A more balanced look at Smith's arguments including his earlier work on the moral sentiments shows that happiness does not lie in mere self-interest (Smith 1790, IV, I. 9) and that we would not think very highly of a butcher, brewer, or baker who only considered her financial interest and never strove to accomplish anything of intrinsic ethical value via her craft. This "self-love" to which Smith refers will foster in the craftsman a desire to hone her craftsmanship and to create a quality product in which she may take pride. Indeed, Smith was aware of the problem of anonymity in large cities where the worker falls into a condition of "obscurity and darkness," where "his conduct is observed and attended to by nobody, and he is therefore very likely to neglect it himself, and to abandon himself to every sort of low profligacy and vice" (Smith 1790, V, I. 12). Furthermore, as Aristotle (2011) pointed out long ago, we are social beings whose self-love is rooted in a concern for others. A growing sociobiological literature affirms that concern for others, a.k.a. "eusociality" is an adaptive trait in myriad species including our own and that it is equally motivating as the drive of individual self-interest, both of which are indispensible for us to thrive individually and as groups (Nowak et al. 2010).

Some have argued that an overemphasis on self-interest can produce an environment in which persons lacking empathy can thrive at the expense of others. Babkiak et al. (2010) have shown that persons with a clinical inability to experience empathy may be 2.5 times as prevalent among corporate professionals than in the wider population. Boddy (2011) suspects that "corporate psychopaths" at major financial corporations played a key role in precipitating the Great Crash of 2008. Clearly, we need business leaders to be mindful of their potential impact on others, and to believe that those others deserve a place in their business calculus.

A close look at the evidence surrounding us, however, suggests that our policy structures are moving away from a consideration for others, and instead toward having the option to simply pay one's way out of the burden of such considerations. Thus, carbon offsets may actually provide a way for consumers and businesses to simply buy their way out of ever enacting the broader changes in behavior those costs were intended to incentivize (Skopek 2010). Why shoulder the same burdens as otherwise equivalent Americans by waiting in line at the airport, amusement park, stadium, concert, or congressional hearing (Sandel 2012, pp. 17-42), when you can simply pay more and be given preferential treatment? In many ways, "the burden of good governance [has shifted] from the task of cultivating civic virtue to the challenge of designing institutions that work tolerably well in its absence" (Bowles 2011, p. 3).

The challenge of such market-based structures for curtailing the responsibility of carrying a shared burden is that the economic motives they reinforce tend to crowd out moral ones (Atiq 2014). In a widely cited study of Israeli daycare centers, late child pickups nearly doubled after a small fine was instituted for late pickup of 10 minutes or more (Frey 1997; Gneezy and Rustichini 2000). With the introduction of the fine, the daycare center tacitly had shifted the meaning of the tardiness from "I might be inconveniencing the staff who would like to go home" to "I paid for the right to be late." Remarkably, the increased rate of tardiness persisted even after the fines were removed, indicating that economic incentives can continue to inhibit mindfulness of others by hardening self-interested attitudes (Gneezy and Rustichini 2000). If past research is any indication, such charges will only increase at daycare centers, summer camps, and pet kennels, reinforcing a self-interested mindset that re-frames fines as fees.

Still, social and economic incentives are often closely intertwined. At the interpersonal level, financial incentives can sometimes strengthen the bonds of intimacy (Zelizer 2000). And at the societal level, those who feel a strong civic bond to their political system may experience moral crowding-in even while financially incentivized. Conversely, citizens dissatisfied with their political system are willing to breach their social contract whenever they can expect to do so at low cost (Frey 1997). Currently, just $19 \%$ of US citizens express trust in their government all or most of the time, with only $20 \%$ saying their government is well run (PewResearch 2015). This may compound the moral crowding-out effect, and it may be impossible to entirely disentangle the effects of economic incentives on culture from the effects of culture on economic incentives. 
In any case, the widely observed tendency in countries such as the US of using wealth to absolve oneself from having to show mindfulness of others might foster an atmosphere of callous disregard for others, creating negative externalities to both specific others and to society in aggregate. In a fascinating study on the potential link between wealth and mindfulness of others, drivers of luxury cars were three to four times more likely to not stop for pedestrians at an unprotected crosswalk (Piff et al. 2011), sometimes almost running over surrogates rather than letting pedestrians pass as required by law (and good manners) (PBS 2013). Members of this group were also more likely to cut off other drivers, rather than wait their turn as both law and custom require (Piff et al. 2011). Research subjects of higher self-identified socioeconomic status exhibit less egalitarian behavior in trust games (Piff et al. 2010) and lower generosity in dictator games even when controlling for such things as religiosity (Piff et al. 2010).

One might argue that such observations tell us nothing about the link between wealth and consideration for others per se, or that the outcomes may be simply predispositions, and thus, there is little we can do. Still, other studies show that antisocial behaviors can be primed psychologically through manipulations that evoke wealth or social class differences. Subjects primed to consider themselves above others in terms of money, education, and employment have trouble identifying emotions in the faces of others (Kraus et al. 2010). When told that candy was intended for children then left alone in the room, individuals primed to consider themselves more well off than others took twice as much candy as those primed to be less well off (PBS 2013). Additionally, individuals primed to consider how pursuing their own self-interest can be good were four times more likely to falsify the results of a dice game, just to win credits for a $\$ 50$ cash prize (PBS 2013) and expressed a higher willingness to engage in unethical business practices, including "bait and switching" customers or gifting merchandise to friends or themselves (Piff et al. 2011). Such data suggest that markets may actually reward unethical behavior by incentivizing and reinforcing a self-interested mindset, crowding out broader moral concerns. Fortunately, behavioral research has shown that empathic priming can dramatically increase altruistic tendencies (Batson 1995; Piff et al. 2010). These results indicate that one's degree of consideration for others is not merely a genetic predisposition, but also highly malleable.

In the following sections, we introduce and defend a new theoretical construct-moral self-awareness-and discuss how the construct is linked to important dimensions of human nature. We then propose a pathway forward that encourages virtuous behavior more broadly.

\section{Moral Self-Awareness}

We define moral self-awareness (MSA) as an alternative motivational mindset to economic self-interest. It is a mindset informed by reflection on moral identity, namely what one's actions say about oneself given (a) the negative impact on others or society that one's action may effect, and (b) what one contributes to others and/or society by taking a given action. We are not suggesting that these considerations offer a complete picture of moral motivation. Only that they offer a more integrated motivational mindset that may be harnessed to optimize social welfare more effectively than the mere fuel of self-interest. To engage this reflection, the individual relies on three characteristics of the human moral experience: pride, shame, and guilt.

\section{Moral Identity}

This is the overarching dimension of MSA, namely the reflection on what a given action reveals about one's individual or collective moral identity. This was the foundation of our discussion in "The Moral Dimensions of Markets" section on the moral progress of markets and the three conditions that we have modified across time to bring us closer to the type of society we aspire to be. Moral identity is the central component of our MSA model since "without a direct implication to the self-concept, moral reasoning, moral cognition, or even a feeling of goodwill need not necessarily lead to moral action" (Aquino and Reed II 2002). The social psychological literature has established a clear relationship between the self-importance of moral identity and moral thought and action (Aquino and Reed II 2002; Reed II and Aquino 2003). It hence functions as a powerful motivator that we believe can be leveraged to effect a pivot from the homo-economicus to the homo-virtus mindset.

This dimension is driven by both pride and shame and constitutes the essence of one's moral self-awareness. Bernard Williams argues that the modern mind tends to conceive moral blame more in terms of guilt, namely by recognizing the negative consequences of one's actions and reflecting in dismay, "Look at what I've done!" In contrast, shame is a reaction to what an immoral act reveals about oneself to oneself, exclaiming, "Look at who I've become!" and was much more operative in ancient Greece (Williams 1994). This distinction is useful to our analysis, because shame is what best exposes excessively self-oriented attitudes, which may not have immediately observable negative impacts on others (e.g., global warming) and thus go on unabated by consequence-based guilt. In short, 
one may not feel guilt for being a purely self-interested actor, but one may feel ashamed for being one.

It is due to these reflections on self that one can observe an interaction and react emotionally to it, even though one is not a participant. This occurs because one can place oneself in the interaction by proxy and posit how one might have responded if given the chance. This means that selfconstrual contains aspirational elements of one's best self. It is this self-construal that is the wellspring of both pride (which manifests with actions in line with one's self-construal) and shame (which manifests with actions that fall out of line with that same self-construal). We see evidence of both at work in myriad occurrences of civic mindedness including the nuclear waste studies, tax evasion study, and voter participation studies cited in the "A Pathway Forward" section to follow.

\section{Negative Impact on Others}

This is the reflection on the negative impact that one's individual or collective actions may create and is driven by both shame and guilt. This is perhaps the most easily acknowledged aspect of moral reflection; it is one that children learn at the earliest levels of moral development when one's naked self-interest is still the primary driver of action, except when causing direct harm to others. Kohlberg (1984) conceives this as a bare bones egalitarianism necessary for self-interested exchange and reciprocity. Intriguingly, the self-interested rational actor model of economics reflects this level of moral development. Economic incentives serve to encourage and reinforce this rudimentary moral frame and inhibit moral progress. Nevertheless, it remains a fundamental aspect of MSA, allowing us to begin to interact productively with others by acknowledging and avoiding the potential negative impact of our actions. At first, such reflections are triggered by others drawing attention to how the focal individual took actions that created negative impacts on others. Gradually, with moral maturity one comes to recognize and foresee these impacts oneself. We shall explore and distinguish these points in the next section.

\section{Potential Contribution to Others}

This is the reflection on what one may contribute to others and/or society by taking a given action. Much of this motivational attitude is largely shaped by pride. The Oxford Dictionaries define pride as "a feeling or deep pleasure or satisfaction derived from one's own achievements, the achievements of those with whom one is closely associated, or from qualities or possessions that are widely admired" (Oxford 2013). This means that pride is connected with a positive self-construal for one's behavior or for the behavior of associates. One area where this manifestation of pride is most visible is in civic mindedness and citizenship, constructs that are both psychological and sociological at the same time. Individuals called for jury duty are often shown videos that appeal to civic mindedness; although remuneration for jury duty is small and the inconvenience large, justice may not be served if the jurors going into their deliberations are angered by the experience. To help minimize such possibilities, appeals to civic mindedness are common (State of New York 2012).

Research has demonstrated the power of such appeals. In a classic study on tax evasion, subjects were $8 \%$ points less likely to cheat on their income tax returns (on average) when civic mindedness was emphasized than when subjects were threatened with legal sanctions (Schwartz and Orleans 1967). And in a fascinating study on the willingness of individuals in Switzerland to accept a nuclear waste repository in their vicinity (Frey 1997), willingness dropped 50\% when substantial monetary rewards were offered (Sandel 2012, p. 115). While such high recoil rates will surely have a cultural component, similar results have been observed cross-culturally (Kunreuther and Easterling 1996), including at the Hanford, Washington site, where support dropped when tax incentives were included (Dunlap et al. 1993). Thus, we see push-back against shifting the frame of reference from doing one's civic duty to being paid to accept the facility. It is important to note that whereas the shift in the daycare center case happened because the payment represented a fine for behavior that would otherwise create guilt in the late parent, the attempt to utilize financial payments in the nuclear waste cases was not linked with guilt. Instead, it was linked with pride in one's actions to take on a burden that would help the greater good-a social mindfulness, so to speak, and avoidance of the shame that accepting money might bring upon oneself.

In summary, one's MSA is shaped by a convergence of three powerful self-conceptual forces-namely guilt, shame, and pride - and their interactions and complementarities, which may be harnessed to optimize social welfare where economic self-interest falters.

\section{A Pathway Forward}

As the above has suggested, the introduction of economic considerations creates a powerful framing effect for decision makers. Economic markets or the movement of money through market transactions often focuses attention on materialistic pursuits such as bargaining, negotiation, and competition (Falk and Szech 2013, p. 708). Even with identical payouts, individuals will take on more self-interested behaviors when a dilemma is presented in a way 
that elicits an economic frame than when presented in a way that elicits a noneconomic frame (Pillutla and Chen 1999). Individuals reminded of money tend to behave in more selfish ways (Vohs et al. 2006) and engage in cheating more often (Gino and Pierce 2009). These cognitive frames are so powerful that for many there appears to be true incompatibility between self-interest and consideration of others (Kasser et al. 2007). While scholars attribute these responses to everything from envy (Gino and Pierce 2009) to entitlement (Piff et al. 2011), the key lesson of this research is that individuals can be primed experimentally. This means that they are learned psychological or sociological phenomena and can thus be reversed, something impossible if the effects were genetic predispositions.

We argue that to combat this tendency toward prioritizing self-interest over mindfulness of others, we must create a shift in how individuals respond to stimulus. This must happen first at the individual level, where managers and employees are making day-to-day decisions that carry various potential consequences (both positive and negative). The same shift can also happen at higher, more collective levels, such as the organizational level and industry level. Getting there, however, will require the bringing together of two unique perspectives-a systems theory approach and virtue ethics—and may require upwards of four distinct stages of development.

Systems theory is a perspective that the different moving parts of a firm-finance, R\&D, manufacturing, distribution, and so on-are part of a unified system and should not be viewed as divorced from each other (Forrester 1958; Roberts 1978). Successful financing provides the money needed to do $R \& D$, which yields innovative products that drive customer purchases, which demand more manufactured goods, and so on. Thus, there are levers that can be pulled by actors, which create both immediate effects and delayed effects, which turn into feedback to inform subsequent decision making. In short, systems theory describes the sensemaking process that every actor undergoes when faced with decision points and later decision points (Weick 1995). The logic has been applied to everything from whistle-blowing decisions (Andrade 2015) and structuring HRM practices (Buller and McEvoy 2016) to understanding biological and ecological systems (Wilkinson 2006).

At the most base level, after a focal actor engages in behavior that brings negative externalities upon others, observers will act as the source of feedback. At the individual level, this often takes the form of shaming or guilting the actor into changing his or her behavior. As an example, even after being primed in a Tragedy of the Commons experiment to be self-interested, subjects gradually learned to temper their self-interest in subsequent rounds of decision making by being shamed by other subjects who were left with fewer resources (Sadowski et al. 2013, 2014). Ultimately, all subjects in the experiment showed preference for lowered individual returns in favor of equitable and sustainable longer-term outcomes. This type of experiment demonstrates the power of feedback from others in curtailing individual-level behavior that creates negative externalities for others.

At the organizational level, feedback usually comes from social movement activists and journalists. Activists employ various tactics to achieve behavioral change in their targets, including letter writing campaigns, boycotts, and protests (Lenox and Eesley 2009). Letter writing campaigns represent many-to-one feedback to the organizational target and need not be known by the broader public at large (Taylor and Van Dyke 2004). In contrast, boycotts and protests usually engage the media in order to magnify the impact of activist efforts through media portrayals (Reitman 1996). These performances in the public sphere are intended to raise questions about the target's conformity with societal norms, values, or beliefs (King and Soule 2007) and often achieve those aims. For their part, journalists can expose or condemn organizations for behavior deemed unacceptable (Hallin 1989, p. 117). This type of shaming or guilting represents a widely known means of altering the behavior of organizations.

It is also important to note that while considerable attention has been paid to shaming as a tool for counteracting the crowding out of moral considerations (Frey and Jegen 2001; Kahan and Posner 1999), excessive use of shaming may be both counterproductive and ultimately unsatisfying to those advocating either egalitarian or individualistic values (Kahan 2006). Public shaming has been shown to backfire when the target feels powerless to act otherwise or when the punishment is considered too severe (Combs et al. 2010; Kahan 2006). Because this level of awareness relies on observers to sanction through shaming, it runs the risk of counterproductivity and backlash. Guilting, however, has been shown to have potentially more constructive outcomes by being less damning and offering more positive reparative behaviors (Tangney et al. 2007). As a result, appeals to shame and guilt should be framed whenever possible to include a countervailing appeal to corrective pride, which becomes increasingly salient with expanding MSA.

At the second level, the focal actor is more self-reflective. Rather than outside observers bringing the negative externalities to the focal actor's attention, the actor him- or herself takes on the role as his/her own source of feedback. The mechanism by which this self-reflection happens is observation of others' behavior or an extension of consideration beyond every day stakeholders. As an example of the observation of others at the individual level, Cialdini et al. (1991) showed that subjects were 2.5 times less likely 
to litter in a room containing swept litter than in an unswept litter-strewn room. Seeing how individuals do not engage in effort unless it is considered important to them, observing the swept nature of the litter informs the observer that a clean room is desirable, thereby increasing the propensity of the observer to also exert effort to keep the room clean.

Similarly, consideration of social signals in the other direction often leads to the opposite behavior. Observing a more littered room, for example, communicates to us that it is acceptable to litter there, after all "if everyone else is doing or thinking or believing it, it must be a sensible thing to do or think or believe" (Cialdini et al. 1991, p. 203). It is important to note that the entire "broken window" theory of law enforcement is based on this logic-untended property becomes "fair game for people out for fun or plunder and even for people who ordinarily would not dream of doing such things and who probably consider themselves law-abiding" (Kelling and Wilson 1982, n.p.). By signaling that others think broken windows are appropriate, broken windows become appropriate, and people oblige themselves with the task of breaking more windows, leading to broader decay of the community. Thus, the broken windows theory calls for repairing small incidents of decay before they catalyze broader incidents, and importantly, that repair work must be done irrespective of whether the individual responsible is caught (i.e., an example of the basest level from above). A window broken by a hailstorm could have just as much impact as one broken accidentally by a baseball or purposely by a crowbar-it is the observable outcome that provides a basis for self-reflection and a justification for one's own actions as desirable or undesirable.

At the third level, the focal actor becomes forward looking, conceiving of the possible negative externalities before taking action. This is akin to Aristotle's arguments concerning practical reasoning (Aristotle 2011). This forward-looking behavior often comes after self-reflection on prior behavior leads to an internal sense of guilt or shame (rather than one imposed by third-party observers seeking to modify the actor's behavior). At one point during Sadowski et al.'s (2013, p. 1335) Tragedy of the Commons experiment, for example, one participant anxiously asked aloud, "Are we bad people?" While vocalized within a group, the catalyst of the rhetorical question was not to shame or guilt the others in the group (as per the basest level above), but rather to try to reconcile the inconsistency between one's prior action and one's perception of self. This "moral identity crisis" represents an important step for an individual moving toward the highest level of moral self-awareness, and we argue will curtail behaviors with potential negative externalities as the individual moves into the future.
At the pinnacle of these attempts to curtail negative externalities before they appear are individuals who rely on an awareness of self, both as a decision maker and as someone with an internal moral compass that provides guidance in times of judgment (Schwartz 1977). For such individuals, sanctions are internal to the individual, exemplified in regret for past actions, anticipated regret for potential actions (Zeelenberg 1999) and contrite efforts to not participate in similar behavior in the future (e.g., feeling self-conscious for forgetting a soda can in a room) (Zeelenberg and Beattie 1997).

At the fourth, and highest, level, the focal actor becomes forward looking, conceiving not of the possible negative externalities and avoiding action (as in the third level), but rather conceiving of the possible positive externalities of certain actions and purposely engaging in those actions to bring about those positive outcomes for others. At this highest level, individuals internalize the ideal of the self as potential hero rather than a potential villain (Golpadas 2014). By recognizing that one is part of a broader system and taking positive actions to help the system, one selfactualizes at the same time as benefitting others. At best, these decisions are conscientiously habit-forming, bringing persons closer to becoming whom they normatively wish to be (Aristotle 2011) - a truly virtual ethical manifestation of self within a broader system.

There is evidence that businesses themselves have undergone a similar level of self-reflection and conscientious other-minded orientations. Eskom was an all-white power service provider in South Africa during the Apartheid era; even before Apartheid fell, the firm began reflecting on the type of firm "it should be as a national power company in a country where the majority of the population was nonwhite, rural and poor" and transformed itself accordingly (Werhane 2002, p. 40). US carpet maker Interface famously underwent a similar self-reflection and mid-course correction (Anderson 1998). The appearance of such firms-as well as so-called benefit corporations (Mickels 2009)—is testament to the possibility of a morally progressive capitalism rooted in virtuous management. We argue that the nurturing of these morally aspirational attitudes will be key to a sustainable and successful capitalism.

These four stages toward moral self-awareness are captured in Table 1.

\section{Mechanisms for Change}

Work at the field level suggests that creating a broad shift across many actors in the economy is, in fact, possible via the introduction of powerful new ideas, such as academic theories (Zajac and Westphal 2004). Thus, there is evidence that permanent shifts in how people respond to 
Table 1 Four stages toward moral self-awareness

\begin{tabular}{lllll}
\hline & Recognition of externalities & $\begin{array}{l}\text { Externality } \\
\text { focus }\end{array}$ & System theory focus & Motivators \\
\hline $\begin{array}{l}\text { Level } 1 \\
\text { (Basest level) }\end{array}$ & Via others & Negative & Feedback & Guilt/shame \\
$\begin{array}{l}\text { Level } 2 \\
\text { Level } 3\end{array}$ & $\begin{array}{c}\text { Via reflection on outcomes achieved by } \\
\text { others }\end{array}$ & Negative & Self-feedback & $\begin{array}{c}\text { Guilt/shame/ } \\
\text { pride }\end{array}$ \\
$\begin{array}{l}\text { Vevel } 4 \\
\text { (Highest } \\
\text { level })\end{array}$ & $\begin{array}{c}\text { Via self-actualization of one's internalized } \\
\text { values }\end{array}$ & Positive & $\begin{array}{c}\text { Self-feedback with consideration of the } \\
\text { system } \\
\text { Consideration of the system }\end{array}$ & pride \\
\hline
\end{tabular}

stimulus are possible, though we are not so naïve to believe a shift will be simple or immediate.

One way we propose to begin this shift toward increasing moral self-awareness in decision making is to realize the motivational power of pride and shame, both of which appeal to one's own self-image. This means that neither mechanism of behavioral change requires other individuals to be present or engaging with the focal actor in order for the mechanisms to function. This allows for us to move above the basest level of moral self-awareness and into the higher levels, shifting the responsibility from others admonishing, "Look at what you've done!" to the individual actor thinking to him- or herself, "Look at who I've become!" (Williams 1994). The answer to the latter question represents either pride (in the case of positive selfreflection on one's behavior) or shame (in the case of negative self-reflection on one's behavior), and both have powerful motivating effects.

Several large-scale studies have captured the power of these two mechanisms. In one study involving roughly 180,000 subjects, potential voters were notified in advance via direct mail that their voting participation would become a matter of public record. When households were informed that they would be shown only their own voting records, voter participation increased $4.9 \%$ points. However, when households were informed that they would be shown both their own voting records and the voting records of their neighbors, participation increased $8.1 \%$ points (Gerber et al. 2008). In a separate study that examined whether listing the names of those who voted in the local newspaper (i.e., public praise) would have greater impact than listing the names of those who did not vote (i.e., public shaming), it was the latter that had a greater effect (Panagopoulos 2010). Thus, shaming (with certain caveats) can play a positive role when tied to civic responsibility.

We are also mindful that the introduction of monetary considerations to the decision-making process does create some complexity, but it is not necessarily unilaterally in one direction (i.e., against morally self-aware decisions). Titmuss (1971) argued that banning blood commercialization actually strengthens social bonds by compelling us to give what can only be given. Follow-up studies confirm the argument for certain demographics; the supply of female blood donors is reduced by half when monetary payment is introduced (Mellström and Johannesson 2010). This suggests other dimensions may outweigh monetary considerations. In the case of voting, several locations have adopted compulsory voting policies with small fines used to dissuade non-compliance. Such a system increased participation in Australia on average 30.4\% (Jackman 2001). The fact that fines for non-voters have not morphed into fees (à la the Israeli daycare center) suggests that nonvoting penalties seem to function more as a symbol, indicating what voter participation reveals about a person more than as an economic inhibitor of bad behavior. This is similar to our discussion of the moral conditions of markets-i.e., how we allow markets to function informs us as to who we are and who we want to become. Thus, there appears to be value in connecting decision making to the values that actors hold true, such as civil responsibility, which can extend to both positive and negative externalities as the higher stages of our model described.

More importantly, we need to move to a place where managers no longer say to themselves, "It's not illegal, therefore, I may do it." to a place where individuals instead say, "Even though it's not illegal, I'm still not going to do it." and "Even though no one may hear about my good actions, I'm still going to do the right thing." and ultimately "Even though I don't have to do the right thing, I'm going to do it anyway." Research suggests that ethical awareness and reasoning skills improve in students after taking classes in business ethics, but that the effect is shortlived (Weber 1990). Clearly, for such mindsets to become "sticky," the attitudes surrounding the mindsets must be 
far more prevalent. The Swedish government has introduced carbon footprint labeling on grocery items (Rosenthal 2009) in an attempt to expose consumers to information that might make them more mindful of the impact of their purchases more frequently. Given that each of these individual actions does precious little on its own, it is likely that consumers are taking pride in lowering their carbon footprints. And there has been a strong push in the US to force food producers to label genetically modified ingredients (Brown 2013), which has been opposed by food industry interests (Sky Valley Chronicle 2013). Such initiatives use the policy apparatus to reduce information asymmetries and spur consideration of potential negative externalities that might arise as a result of purchases ignorant of these considerations. While these initiatives may be helpful, ultimately so long as managers are concerned solely with the interests of their firm, firms will continue to utilize the policy apparatus that they can so powerfully influence to thwart social welfare maximizing activities (Levine and Forrence 1990) and flow like water around existing regulatory constraints whenever possible. Rather than trying to plug every crack in the wall being created by excessively self-interested actions, we need to quash the impetus to create the cracks in the first place.

Finally, it is important to note that our proposal goes in a different direction than Kohlberg (1984), whose model of moral development is not based on an evolving moral selfimage. It also differs from Lawrence \& Nohria (2002), who draw a narrative of the individual driven by more than just the animal-like drive to acquire and defend; their approach relies primarily on sociological data. Similarly, while empathic priming (Batson 1995; Piff et al. 2010) and organizational injustice (Cropanzano et al. 2003) can stimulate altruistic behavior, research on these stimuli suggests they are inadequate to effect long-term change in behavior absent emotional triggers. That is important because we cannot rely exclusively on emotions to behave virtuously in every circumstance; emotive priming actually can cloud one's moral judgment (Côté et al. 2012) and compassion fatigue may ensue (Kinnick et al. 1996). Moreover, there is substantial evidence that persons behave altruistically without priming, according to internalized moral motivational frames such as the deontic (Turillo et al. 2002), or utilitarian and virtue ethical (Friedland and Cole 2013). We believe that such virtuous attitudes are undertaken both behaviorally (as a matter of conditioning) and cognitively (as a matter of analytical reflection and self-reflection) and that moral progress functions chiefly as a result of the latter, which is constitutive of moral character (Cohen and Morse 2014). We would also like to underscore that our model should be taken as a complement to ethics of care approaches emphasizing the role of social relations in shaping moral identity.

\section{Conclusion}

Despite inevitable ebbs and flows, there is consistent pressure in societal expectations with respect to business ethics (Chandler 2011; Vogel 2005, Ch. 3) and initiatives that embrace a more virtuous form of capitalism are becoming more prevalent. These range from the "buy one, donate one" programs of Tom's and Warby Parker; to the certifications provided by the Fair Labor Association and Rainforest Alliance; to the economic empowerment initiatives of Grameen Bank and ACCION. Given how quickly the socially responsible sector is growing, it would appear that a more morally progressive capitalism is a social and economic opportunity.

In this paper, we have argued that moral self-awareness (MSA) is anchored in a moral identity shaped by (a) the negative impact on others or society that one's action may effect, and (b) what one contributes to others and/or society by taking a given action - which can be motivated through three distinct stimuli-guilt, shame, and pride. We anticipate that the progression could take individuals broadly through four stages, wherein feedback about the negative effects of one's past actions are eventually supplanted by prescriptive consideration of the positive effect one may have through virtuous future actions. The long-term goal, of course, is to raise the level of engagement of the decision maker-whether acting as a private individual or a manager of corporate resources-toward more morally mindful actions.

We invite research into how virtuous management, particularly via appeals to MSA, can function to increase social welfare when economic incentives fail to do so. It would be interesting to learn, for example, if appeals to MSA do a better job than financial penalties in reducing late daycare pickups, and if such appeals are better at inspiring pro-social organizational behaviors in the workplace. Myriad campaigns now employ appeals to civic pride for responsible consumption and environmental stewardship; the "Benefit Corporation" is a conspicuous example (Mickels 2009). It would be good to know the extent to which consumers are responding. Another way scholars may be able to assess whether virtue is becoming more prevalent is to monitor the attributions made by top management teams when problems arise. Classically, individuals will seek to take credit for good news, yet deflect responsibility for bad news by blaming causes other than themselves (Kelley and Michela 1980). As virtuous decision making gains more prevalence among business leaders, one would expect that situational attributions will decrease, as managers more readily admit shortcomings and promise to live up to higher standards. 


\section{Compliance with Ethical Standards}

Conflict of interest Julian Friedland and Benjamin M. Cole declare that neither has any conflicts of interest.

Human Participants or Animals This article does not contain any studies with human participants or animals performed by any of the authors.

\section{References}

Anderson, R. C. (1998). Mid-course correction: Toward a sustainable enterprise: The interface model. Atlanta: The Peregrinzilla Press.

Andrade, J. (2015). Reconceptualizing whistleblowing in a complex world. Journal of Business Ethics, 128(2), 321-335.

Aquino, K., \& Reed, A., II. (2002). The self-importance of moral identity. Journal of Personality and Social Psychology, 83(6), $1423-1440$.

Aristotle. (2011). Aristotle's Nicomachean ethics. Chicago, IL: University of Chicago Press.

Arrow, K. (1971). The theory of discrimination. Presented at Conference on 'Discrimination in Labor Markets,' Industrial Relations Section, Woodrow Wilson School \& Conference Office of Princeton University, Oct 7-8.

Atiq, E. H. (2014). Why motives matter: Reframing the crowding out effect of legal incentives. Yale Law Journal, 123, 1070-1116.

Babkiak, P., Neumann, C. S., \& Hare, R. D. (2010). Corporate psychopathy: Taking the walk. Behavioral Sciences \& the Law, 28(2), 174-193.

Baker, W. E. (1984). The social structure of a national securities market. American Journal of Sociology, 89, 775-811.

Barton, D. (2011). Capitalism for the long term. Harvard Business Review, 89(3), 84-91.

Batson, C. D. (1995). Prosocial motivation: Why do we help others? In A. Tesser (Ed.), Advanced social psychology (pp. 332-381). Boston, MA: McGraw-Hill.

Bentham, J. (1780). An introduction to the principles of morals and legislation. New York: Dover.

Brennan, G., \& Pettit, P. (2006) The economy of esteem: An essay on civil and political society. Oxford University Press.

Boddy, C. R. (2011). The corporate psychopaths theory of the global financial crisis. Journal of Business Ethics, 102(2), 255-259.

Bogus, C. T. (1998). The hidden history of the Second Amendment. University of California at Davis Law Review, 31, 309-407.

Bosse, D. A., Phillips, R. A., \& Harrison, J. S. (2009). Stakeholders, reciprocity, and firm performance. Strategic Management Journal, 30, 447-456.

Bowles, S. (2011). Machiavelli's mistake: Why good laws are no substitute for good citizens. Working Paper Series, Sante Fe Institute.

Brookes, G., \& Barfoot, P. (2009). Global impact of biotech crops: Income and production effects. The Journal of Agrobiotechnology Management \& Economics, 12(2), 184-208.

Brown, S. (2013). Gap narrows in GMO label vote. Capital Press November 13. Salem, OR: Capital Press. Accessed Nov 14, 2013, from http://www.capitalpress.com/article/20131113/ARTI CLE/131119956/131111318.

Buller, P. F., \& McEvoy, G. M. (2016). A model for implementing a sustainability strategy through HRM practices. Business and Society Review, 121(4), 465-495.

BusinessWeek. (2009). \$10.2 trillion: Estimated cumulative stock losses for American households since the end of 2007 with the Dow Jones Wilshire 5000 Composite Index down by nearly 50\% (Vol. 13). New York: The McGraw-Hill Companies.
Chandler, D. (2011). Organizations and ethics: Field-level versus firm-level sources of adoption and implementation. In Academy of management conference, San Antonio, TX.

Chang, H.-J. (2008). Bad Samaritans: The myth of free trade and the secret history of capitalism. New York: Bloombury Press.

Cialdini, R. B., Kallgren, C. A., \& Reno, R. R. (1991). A focus theory of normative conduct: A theoretical refinement and reevaluation of the role of norms in human behavior. Advances in Experimental Social Psychology, 24, 201-234.

Coase. (1937). The nature of the firm. Economica, 4(16), 386-405.

Cohen, T. R., \& Morse, L. (2014). Moral character: What it is and what it does. Research in Organizational Behavior, 34, 43-61.

Combs, M. B. (2005). "A measure of legal independence": The 1870 Married Women's Property Act and the portfolio allocations of British wives. Journal of Economic History, 65(4), 1028-1057.

Combs, D. J. Y., Campbell, G., Jackson, M., \& Smith, R. H. (2010). Exploring the consequences of humiliating the moral transgressor. Basic and Applied Social Psychology, 32, 128-143.

Congress. (2010). The Patient Protection and Affordable Care Act, 111th Congress, Public Law No: 111-148, March 23. https:// www.congress.gov/111/plaws/publ148/PLAW-111publ148.pdf.

Conway, E. (2008). 'Ninja' loans explode on sub-prime frontline. The Telegraph March 3. London: Telegraph Media Group Limited. Accessed Nov 8, 2013, from http://www.telegraph.co.uk/finance/ economics/2785403/Ninja-loans-explode-on-sub-prime-front line.html.

Côté, S., Piff, P. K., \& Willer, R. (2012). For whom do the ends justify the means? Social class and utilitarian moral judgment. Journal of Personality and Social Psychology, 104(3), 490-503.

Cropanzano, R., Goldman, B., \& Folger, R. (2003). Deontic justice: The role of moral principles in workplace fairness. Journal of Organizational Behavior, 24, 1019-1024.

David, P. A. (1985). Clio and the economics of QWERTY. American Economic Review, 75(2), 332-337.

Dessy, S., \& Pallage, S. (2004). A theory of the worst forms of child labour. Economic Journal, 115(500), 68-87.

Diamond, J. (2006). Collapse: How societies choose to fail or succeed. New York: Penguin Press.

Dunlap, R. E., Rosa, E. A., Baxter, R., \& Mitchell, R. (1993). Attitudes toward siting a high-level nuclear waste repository at Hanford, Washington. In R. E. Dunlap, M. E. Kraft, \& E. A. Rosa (Eds.), Public reactions to nuclear waste. Durham, NC: Duke University Press.

Falk, A., \& Szech, N. (2013). Morals and markets. Science, 340(May), 707-711.

Forrester, J. W. (1958). Industrial dynamics: A major breakthrough for decision makers. Harvard Business Review, 36(4), 37-66.

Fowler, C., \& Mooney, P. (1996). Shattering: Food, politics, and the loss of genetic diversity. Tucson, AZ: University of Arizona Press.

Frey, B. S. (1997). A constitution for knaves crowds out civic virtues. The Economic Journal, 107(443), 1043-1053.

Frey, B. S., \& Jegen, R. (2001). Motivation crowding theory. Journal of Economic Surveys, 15(5), 589-611.

Friedland, J., \& Cole, B. M. (2013). Expanding the motivations for altruism: A philosophical perspective. Journal of Organizational Behavior, 34(8), 1202-1206.

Friedman, M. (1970). The social responsibility of business is to increase its profits. New York Times Magazine, September 13. New York: The New York Times Company.

Gerber, A. S., Green, D. P., \& Larimer, C. W. (2008). Social pressure and voter turnout: Evidence from a large-scale field experiment. American Political Science Review, 102(1), 33-48.

Giacalone, J. (2001). Analyzing an emerging industry: Viatical transactions and the secondary market for life insurance policies. Southern Business Review, 27(1), 1-7. 
Giacalone, R. A., \& Thompson, K. R. (2006). Business ethics and social responsibility education: Shifting the worldview. Academy of Management Learning \& Education, 5(3), 266-277.

Gino, F., \& Pierce, L. (2009). The abundance effect: Unethical behavior in the presence of wealth. Organizational Behavior and Human Decision Processes, 109(2), 142-155.

Girion, L. (2009). Blue cross praised employees who dropped policyholders, lawmaker says. Los Angeles Times June 17. Los Angeles: Los Angeles Times Media Group.

Gneezy, U., \& Rustichini, A. (2000). A fine is a price. Journal of Legal Studies, XXIX, 1-17.

Golpadas, A. (2014). Marketplace sentiments. Journal of Consumer Research, 41(4), 995-1014.

Granovetter, M. (1985). Economic action and social structure: The problem of embeddedness. American Journal of Sociology, 91(3), 481-510.

Griffin, J. M., \& Tang, D. Y. (2011). Did subjectivity play a role in CDO credit ratings? Journal of Finance, 67(4), 1293-1328.

Hallin, D. C. (1989). The uncensored war: The media and Vietnam. London: University of California Press.

Hardin, G. (1968). The tragedy of the commons. Science, 162(3859), 1243-1248.

Hayek, F. A. (1945). The use of knowledge in society. American Economic Review, 35(4), 519-530.

Jackman, S. (2001). Voting: Compulsory. In N. J. Smelser \& P. B. Baltes (Eds.), International encyclopedia of the social \& behavioral sciences (pp. 16314-16318). Amsterdam: Elsevier.

Johnston, K. (2013). The messy link between slave owners and modern management. Forbes January 16. Jersey City, NJ: Forbes Media LLC. Accessed Oct 10, 2013, from http://www.forbes. com/sites/hbsworkingknowledge/2013/2001/2016/the-messylink-between-slave-owners-and-modern-management/.

Jones, T., \& Felps, W. (2013). Stakeholder happiness enhancement: A neo-utilitarian objective for the modern corporation. Business Ethics Quarterly, 23, 349-379.

Kahan, D. M. (2006). What's really wrong with shaming sanctions. Faculty Scholarship Series, Yale Law School Paper 102.

Kahan, D. M., \& Posner, E. A. (1999). Shaming white-collar criminals: A proposal for reform of the Federal Sentencing Guidelines. Journal of Law and Economics, 42(S1), 365-392.

Kasser, T., Cohn, S., Kanner, A. D., \& Ryan, R. M. (2007). Some costs of American corporate capitalism: A psychological exploration of value and goal conflicts. Psychological Inquiry, 18, $1-22$.

Kelley, H. H., \& Michela, J. L. (1980). Attribution theory and research. Annual Review of Psychology, 31, 457-501.

Kelling, G. L., \& Wilson, J. Q. (1982). Broken windows: The police and neighborhood safety. The Atlantic March 1, Accessed Nov 5, 2013, from http://www.theatlantic.com/magazine/archive/ 1982/2003/broken-windows/304465/.

King, B., \& Soule, S. A. (2007). Social movements as extrainstitutional entrepreneurs: The effect of protests on stock price returns. Administrative Science Quarterly, 52, 413-442.

Kinnick, K. N., Krugman, D. M., \& Cameron, G. T. (1996). Compassion fatigue: Communication and burnout towards social problems. Journalism and Mass Communications Quarterly, 73(3), 687-707.

Klein, N. (2007). The shock doctrine. New York: Metropolitan Books.

Knight, M. (2013). Western black rhino declared extinct. CNN November 6, Accessed Nov 6, 2013, from http://www.cnn.com/ 2011/2011/2010/world/africa/rhino-extinct-species-report/index. html.

Kohlberg, L. (1984). The psychology of moral development (Vol. 2). New York: Harper \& Row.
Koppelman, A. (2010). Forced labor, revisted: The Thirteenth Amendment and abortion. Northwestern University School of Law Scholarly Commons, Faculty Working Papers Paper 32.

Kraus, M. W., Cote, S., \& Keltner, D. (2010). Social class, contextualism and empathic accuracy. Psychological Science, 21, 1716-1723.

Kunreuther, H., \& Easterling, D. (1996). The role of compensation in siting hazardous facilities. Journal of Policy Analysis and Management, 15(4), 601-622.

Lawrence, P. R., \& Nohria, N. (2002). Driven: How human nature shapes our choices. San Francisco: Jossey-Bass.

Lazerson, M. (1995). A new phoenix? Modern putting-out in the Modena knitwear industry. Administrative Science Quarterly, 40, 34-59.

Lenox, M. J., \& Eesley, C. E. (2009). Private environmental activism and the selection and response of firm targets. Journal of Economics \& Strategy, 18(1), 45-73.

Levine, M. E., \& Forrence, J. L. (1990). Regulatory capture, public interest, and the public agenda: Toward a synthesis. Journal of Law Economics and Organization, 6, 167-198.

Martin, S. L. (2003-2004). Corporate-owned life insurance: Another financial scheme that takes advantage of employees and shareholders. University of Miami Law Review, 58, 653.

Mellström, C., \& Johannesson, M. (2010). Crowding out in blood donation: Was Titmuss right? Journal of the European Economic Association, 6(4), 845-863.

Mickels, A. (2009). Beyond corporate social responsibility: Reconciling the ideals of a for-benefit corporation with director fiduciary duties in the U.S. and Europe. Hastings International \& Comparative Law Review, 32, 271.

Na, J. (2011). Thousands camp out for job fair as jobless rate rises. ABC World News August 18. New York: Yahoo!-ABC News Network.

Nowak, M. A., Tarnita, C. E., \& Wilson, E. O. (2010). The evolution of eusociality. Nature, 466(7310), 1057-1062.

Oxford (2013). Definition of pride in English. Oxford Dictionaries, Accessed Nov 3, 2013, from http://www.oxforddictionaries.com/ us/definition/american_english/pride.

Panagopoulos, C. (2010). Affect, social pressure and prosocial motivation: Field experimental evidence of the mobilizing effects of pride, shame, and publicizing voting behavior. Political Behavior, 32, 369-386.

PBS. (2013). Money on the mind. PBS NewsHour, Making Sense June 21.

Peck, D. (2010). How a new jobless era will transform America. The Atlantic March 1.

PewResearch. (2015). Beyond distrust: How Americans view their government. PewResearch Center for the People \& the Press Nov. 23, Accessed Dec 17, 2016, from http://www.people-press. org/2015/2011/2023/2011-trust-in-government-1958-2015/.

Piff, P. K., Kraus, M. W., Côté, S., Cheng, B., \& Keltner, D. (2010). Having less, giving more: The influence of social class on prosocial behavior. Journal of Personality and Social Psychology, 99, 771-784.

Piff, P. K., Stancato, D. M., Côté, S., Mendoza-Denton, R., \& Keltner, D. (2011). Higher social class predicts unethical behavior. Proceedings of National Academy of Sciences, 109(11), 4086-4091.

Piketty, T. (2014). Capital in the twenty-first century (Arthur Goldhammer, Trans.). Cambridge, MA: Belknap Press.

Pillutla, M. M., \& Chen, X. P. (1999). Social norms and cooperation in social dilemmas: The effects of context and feedback. Organizational Behavior and Human Decision Processes, 78(2), 81-103. 
Pirson, M., \& Turnbull, S. (2011). Toward a more humanistic governance model: Network governance. Journal of Business Ethics, 99(1), 101-114.

Pollak, R. A. (2000). Theorizing marriage. In L. J. Waite, C. Bachrach, M. Hindin, E. Thomson, \& A. Thornton (Eds.), The ties that bind: Perspectives on marriage and cohabitation (pp. 111-125). New York: Aldine de Gruyter.

Porter, M. E., \& Kramer, M. R. (2006). Strategy and society: The link between competitive advantage and corporate social responsibility. Harvard Business Review, 84(12), 78-92.

Potter, W. (2010). Deadly spin: An insurance company insider speaks out on how corporate $P R$ is killing health care and deceiving Americans. New York: Bloomsbury Press.

Reed, A., II, \& Aquino, K. F. (2003). Moral identity and the expanding circle of moral regard toward out-groups. Journal of Personality and Social Psychology, 84(6), 1270-1286.

Reich, R. (2013). The myth of the "free market" and how to make the economy work for us. RobertReich.org Monday, September 16. Accessed Sept 18, 2013, from http://robertreich.org/post/ 61406074983

Reitman, V. (1996). Jesse Jackson to add Honda to boycott, citing lack of diversity in U.S. arm. The Wall Street Journal July 18. New York: Dow Jones \& Company.

Roberts, N. (1978). Teaching dynamic feedback systems thinking: An elementary view. Management Science, 24(8), 836-843.

Rosenthal, E. (2009). To cut global warming, Swedes study their plates. New York Times, October 22. New York: The New York Times Company.

Rothbard, M. N. (2006). For a new liberty: The libertarian manifesto. Auburn, AL: Ludwig von Mises Institute.

Sadowski, J., Seager, T. P., Selinger, E., Spierre, S. G., \& Whyte, K. P. (2013). An experiential, game-theoretic pedagogy for sustainability ethics. Science and Engineering Ethics, 19(3), $1323-1339$.

Sadowski, J., Seager, T. P., Selinger, E., Spierre, S. G., \& Whyte, K. P. (2015). Intergroup cooperation in common pool resource dilemmas: The role of ethical leadership. Science and Engineering Ethics, 5, 1197-1215.

Saez, E. (2013). Striking it richer: The evolution of top incomes in the United States (Updated with 2012 preliminary estimates). Pathways Magazine, Stanford Center for the Study of Poverty and Inequality.

Sandel, M. J. (2012). What money can't buy: The moral limits of markets. New York: Farrar, Straus and Giroux.

Schwartz, S. H. (1977). Normative influences on altruism. Advances in Experimental Social Psychology, 10, 221-279.

Schwartz, R. D., \& Orleans, S. (1967). On legal sanctions. University of Chicago Law Review, 34, 274-300.

SCOTUS. (1980). Diamond v. Chakrabarty, 447 U.S. 303. Supreme Court of the United States, Certiorari to the United States Court of Customs and Patent Appeals No.79-136, Argued: March 17, 1980; Decided: June 1916, 1980.

SCOTUS. (2013). Association for molecular pathology et al. $v$. myriad genetics, Inc., et al. Supreme Court of the United States, Certiorari to the United States Court of Appeals for the Federal Circuit No. 12-398, Argued: April 15, 2013; Decided: June 2013, 2013.

Singer, P. (1981). The expanding circle: Ethics and sociobiology. New York: Farrar, Straus and Giroux.

Sixel, L. M. (2002). Profiting from death? Lawsuit filed in Wal-Mart life insurance case. Houston Chronicle April 15. Houston: Hearst Newspapers.

Skopek, J. (2010). Uncommon goods: On environmental virtues and voluntary carbon offsets. Harvard Law Review, 123, 2065-2087.
Sky Valley Chronicle. (2013). A secret plan to get the feds to kill GMO labeling in every state? Sky Valley Chronicle November 12. Spokane, WA: Sky Valley Media Group, LLC.

Smith, A. (1790). A theory of moral sentiments. London: A. Millar.

Smith, A. (2008). An inquiry into the nature and causes of the wealth of nations. Oxford: Oxford University Press.

Smith, E. B., \& Kuntz, P. (2013). CEO pay 1,795-to-1 multiple of wages skirts U.S. law. Bloomberg April 30, Accessed Nov 8, 2013, from http://www.bloomberg.com/news/2013-2004-2030/ceo-pay-20112795-to-2011-multiple-of-workers-skirts-law-as-sec-delays.html.

Spar, D. L. (2006). The baby business: How money, science, and politics drive the commerce of conception. Cambridge, MA: Harvard Business Review Press.

Speth, L. E. (1993). The Married Women's Property Acts, 1839-1865: Reform, reaction, or revolution? In J. R. Lindgren \& N. Taub (Eds.), The law of sex discrimination (pp. 25-28). Eagan, MN: West Publishing Company.

State of New York. (2012). Jury duty: Now it's your turn to make a difference. New York State Unified Court System.

Steiner, G. (2008). Animals and the moral community: Mental life, moral status, and kinship. New York: Columbia University Press.

Swinton, D. H. (1990). Racial inequality and reparations. In R. F. America (Ed.), The wealth of races: The present value of benefits from past injustice (pp. 153-216). New York: Greenwood Press.

Tangney, J. P., Stuewig, J., \& Mashek, D. J. (2007). Moral emotions and moral behavior. Annual Review of Psychology, 58, 345-372.

Tannehill, M., \& Tannehill, L. (2009). The market for liberty: Is government really necessary? Gilbert, AZ: Laissez Faire Books.

Taylor, V., \& Van Dyke, N. (2004). 'Get up, stand up': Tactical repertoires of social movements. In D. A. Snow, S. A. Soule, \& H. Kriesi (Eds.), The Blackwell companion to social movements (pp. 262-293). Malden, MA: Blackwell Publishing.

The National Academies. (2009). Hidden costs of energy: Unpriced consequences of energy production and use. The National Academy of Sciences, Committee on Health, Environmental, and Other External Costs and Benefits of Energy Production and Consumption.

Titmuss, R. M. (1971). The gift relationship: From human blood to social policy. New York: Vintage Press.

Trinkaus, J., \& Giacalone, J. A. (2002). Entrepreneurial 'mining' of the dying: Viatical transactions, tax shelters, and mind games. Journal of Business Ethics, 36(1-2), 187-194.

Turillo, C. J., Folger, R., Lavelle, J. J., Umphress, E. E., \& Gee, J. O. (2002). Is virtue its own reward? Self-sacrificial decisions for the sake of fairness. Organizational Behavior and Human Decision Processes, 89, 839-865.

University of Virginia. (2004). Historical census browser. University of Virginia, Geospatial and Statistical Data Center. Accessed Nov 3, 2013, from http://mapserver.lib.virginia.edu/.

US Constitution. (1787). Article IV, Section 2, Clause 3. United States Constitution.

US SEC. (2010). Former countrywide CEO Angelo Mozilo to pay SEC's largest-ever financial penalty against a public company's senior executive. US Securities and Exchange Commission October 15 (197).

Uzzi, B. (1997). Social structure and competition in interfirm networks: The paradox of embeddedness. Administrative Science Quarterly, 42(1), 35-67.

Vogel, D. (2005). The market for virtue: The potential and limits of corporate social responsibility. Washington, D.C.: Brookings Institution Press.

Vohs, K. D., Mead, N. L., \& Goode, M. R. (2006). The psychological consequences of money. Science, 314(5802), 1154-1156. 
Weber, J. (1990). Measuring the impact of teaching ethics to future managers: A review, assessment, and recommendations. Journal of Business Ethics, 9(3), 183-190.

Weick, K. E. (1995). Sensemaking in organizations. Thousand Oaks: Sage Publications.

Werhane, P. H. (2002). Moral imagination and systems thinking. Journal of Business Ethics, 38(1/2), 33-42.

Wilkinson, D. M. (2006). Fundamental processes in ecology: An earth systems approach. Oxford: Oxford University Press.

Williams, B. (1994). Shame and necessity. Berkeley: University of California Press.

Wise, S. M. (2000). Rattling the cage: Toward legal rights for animals. Cambridge, MA: Perseus Books.

Wood, B. (1997). The origins of American slavery. New York: Hill and Wang.
Zajac, E. J., \& Westphal, J. D. (2004). The social construction of market value: Institutionalization and learning perspectives on stock market reactions. American Sociological Review, 69(3), 433-457.

Zeelenberg, M. (1999). Anticipated regret, expected feedback and behavioral decision making. Journal of Behavioral Decision Making, 12(2), 93-106.

Zeelenberg, M., \& Beattie, J. (1997). Consequences of regret aversion 2: Additional evidence for effects of feedback on decision making. Organizational Behavior and Human Decision Processes, 72(1), 63-78.

Zelizer, V. A. (2000). The purchase of intimacy. Law \& Social Inquiry, 25(3), 817-848. 